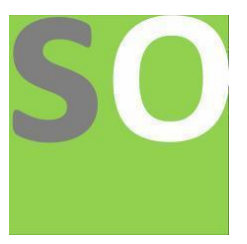

Article title: The Wine Market in Campania Region, Italy: The economic model by Porter applied to the Wine Market of Campania Region

Authors: Francesco Napolitano[1]

Affiliations: N/A[1]

Orcid ids: 0000-0001-8500-9255[1]

Contact e-mail: francesco.napolitano@aol.it

License information: This work has been published open access under Creative Commons Attribution License http://creativecommons.org/licenses/by/4.0/, which permits unrestricted use, distribution, and reproduction in any medium, provided the original work is properly cited. Conditions, terms of use and publishing policy can be found at https://www.scienceopen.com/.

Preprint statement: This article is a preprint and has not been peer-reviewed, under consideration and submitted to ScienceOpen Preprints for open peer review.

DOI: 10.14293/S2199-1006.1.SOR-.PPEOOH0.v1

Preprint first posted online: 24 August 2021

Keywords: wine, italy, campania, regions, economics, porter 


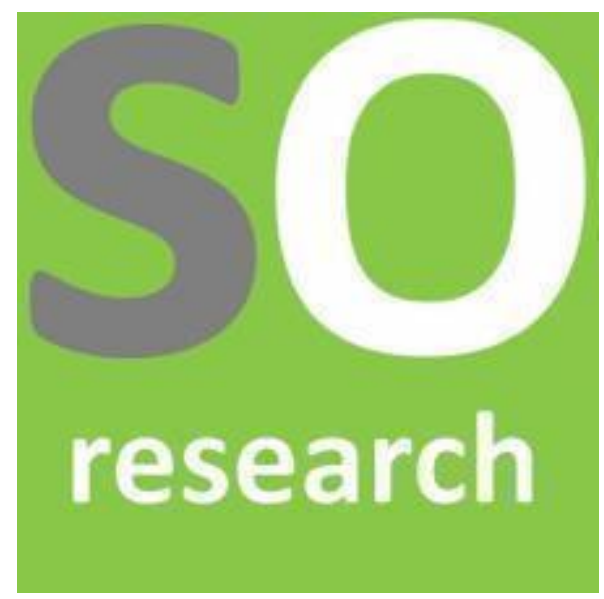

Article title: The Wine Market in Campania Region, Italy

Authors: Francesco Napolitano

Affiliations: N.A.

Orcid ids: 0000-0001-8500-9255

Contact e-mail: francesco.napolitano@aol.it

License information: This work has been published open access under Creative Commons Attribution License: http://creativecommons.org/licenses/by/4.0/, which permits unrestricted use, distribution, and reproduction in anymedium, provided the original work is properly cited. Conditions, terms of use and publishing policy can be found at https://www.scienceopen.com/.

Preprint statement: This article is a preprint and has not been peer-reviewed, under consideration and submitted to ScienceOpen

Preprint first posted online: 23 August 2021

Keywords: Wine, Economy, Porter, Science, Oenology, Italy, Campania, Naples, Salerno, Region, Southern Italy 


\title{
THE WINE MARKET in Campania Region, Italy
}

\author{
Dr. Francesco Napolitano
}

\begin{abstract}
This work is the culmination of three years of study in viticulture and enology. Back in 2017, when I began my training as a sommelier, I found myself to deal with the world of wine, putting aside my diplomatic preparation as Master Graduated in Politics. Rather than devoting myself to the socio-political analysis of relations between states, I looked more interested to study fields planted with vines.

However, especially in Southern Italy - being a sommelier means to be a waiter with a basic knowledge in wine. It's useless to say that my passion for wine could not be limited to a simple table service or to give advices on food-and-wine pairing. In addition to understanding what determines the aromas of wine and the chemical issues that underlie the "bouquet" of flavors and aromas that are in a glass, I wanted to know more about how wine could be marketed or sold.

Plus, the more I tasted fine wines, the more I wondered how it was possible that some wines of my birthplace region Campania were mostly completely unknown beyond national borders. I found it absurd how some regions managed to be famous in the world thanks to some mediocre wines, while Campania was struggling to express its viticultural identity. Yet, for my region, the land is his greatest gift!

The next step of the new sommelier was to attend a university specialization course in Wine Business at the University of Salerno. A course that opened a world for me to an economic approach to the world of wines and that also allowed me to start journalism on behalf of an important Catholic newspaper. The rest is the result of the interest in the economy, already present within me thanks to my previous university education.

This work aims to analyze how the Wine Market of Campania Region is working today. It concluded my second University Degree in Economics. The analysis made use of the support of Prof. Napoli - professor of Strategy and Corporate Governance at the Ecampus Telematic University - and makes use the disciplinary contribution of Michael Porter and his model of Five Competitive Forces.
\end{abstract}




\section{Table of Contents}

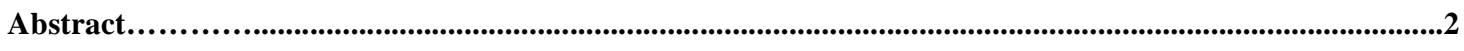

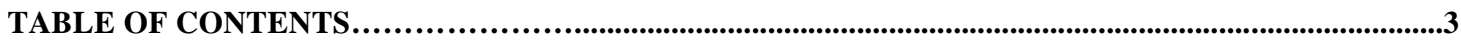

CHAPTER 1 - THE WORLD OF WINE................................................................4

1.1 WINE, AN INTRODUCTIONCRISIS.................................................

1.2 THE VITIS VINIFERA...............................................................

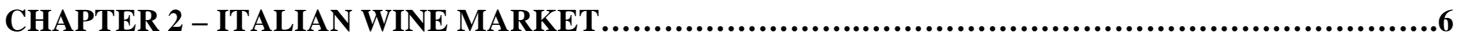

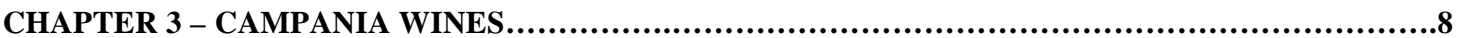

CHAPTER 4 - ECONOMIC ANALYSIS OF CAMPANIA WINE MARKET $\ldots \ldots \ldots \ldots \ldots \ldots \ldots \ldots \ldots \ldots \ldots \ldots \ldots . . .10$

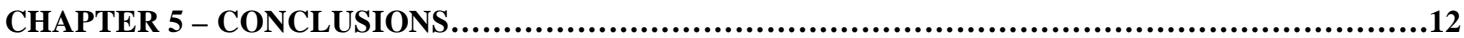

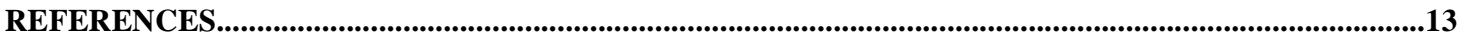




\section{Chapter 1 The World of Wine}

\subsection{Wine, an introduction}

Wine is an ancient drink.

Tradition wants that this drink was "discovered" by chance by nomadic farmers in Eastern Europe. At that time, well before the advent of the Romans, grapes were harvested exclusively for food.

There was no concept of "squeezing" and "fermenting" the grape juice and the clusters of the fruit of the vine were harvested simply for their good flavor.

During the long walks from the fields to the villages, the grapes - stored in large leather bags carried on the shoulder - tended to crush. And, in contact with the air, that sugary liquid that made up the tastiest part of the fruit was transformed into something different. Something intoxicating that, produced in quantity, knew how to give joy to its consumers ${ }^{1}$.

The primacy of discoveries in the wine sector remains in the hands of the monks, who between the Sixteenth and Eighteenth centuries - discovered the methods of refermentation in the bottle (which gives rise to sparkling wines), introduced the use of the glass bottle and of the cork stopper.

As for enlightened men, it is worth mentioning the figure of Cosimo III de 'Medici, lord of Florence, who in 1716 for the first time in history traced the path of the current Denominations of Origin. Although this had already happened in France for at least fifty years, Cosimo was a precursor of this work in our country, delimiting the production areas of Chianti and Carmignano, which - roughly - are the same as today.

Cosimo's example was followed by other Italian lords and princes and in fact - in the mid-sixteenth century - we begin to talk about the production method of Marsala (in Sicily), Teroldego (in today's Trentino) and Moscato di Trani (in Apulia).

\subsection{The Vitis Vinifera}

The vine is a climbing plant of the Rhammales family, consisting of two parts: the hypogeal part, consisting of the root, and the epigeal part, consisting of the woody skeleton and the crown.

The skeleton is made up of branches, shoots and stem (or stump), while the crown is made up of leaves. The function of the roots, which can even reach 4-5 meters deep, is

\footnotetext{
${ }^{1}$ Johnson, H. (2003), Il Vino: storia, tradizioni, cultura, Franco Muzzio Editore
} 
essentially that of anchoring the plant to the ground but also that of nourishing the plant, synthesizing aromas and storing its reserves.

One of the most harmful parasites for the vine is the Filossera, an aphid that attacks the roots of the plant and causes a curved growth.

The European vine suffers particularly from this, so much so that in the 19th century, the arrival of this parasite from America caused its almost total destruction. The catastrophe was such that more than $85 \%$ of the European wine scene was completely destroyed, and only $5 \%$ of the pre-phylloxera vines managed to escape.

In fact, Europe was taken aback by this parasite, which in the Americas - rather than the roots - attacked the leaves, creating yellowish punches called "galls". The damage was such that, to recreate the entire European vineyard, the native vines had to be grafted onto American roots and only after a grueling job was the problem solved ${ }^{2}$.

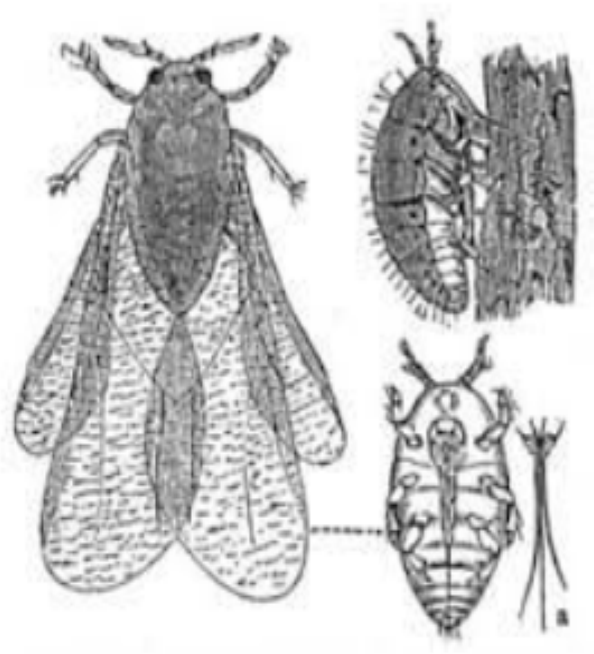

Fig. 1 - The Philloxera Castratrix

\footnotetext{
${ }^{2}$ O.Silvestroni, S.Poni (2018), Manuale di Viticoltura, Ed. Agricole, p.52
} 


\section{Chapter 2 Italian Wine Market}

At the time of Italian Unification, in 1861, Italy had a population of about 20 million inhabitants with a wine production of about 21 million hectoliters.

After the decline in production which took place at the end of the 19th century, due to the spread of Filossera, the production of wine in Italy resumed with great vigor, reaching 50 million hectoliters. These values remain still until the advent of Fascism, which determined - however - the reduction of vineyards in favor of wheat fields (the socalled battle of wheat).

From that moment on, wine was produced less and less and exclusively for family consumption.

With the economic boom of the 1960s, however, around 70 million hectoliters of wine were produced, of which 17 were exported. The 1985 methanol scandal caused a second setback as production dropped to 46 million hectoliters produced, 20 of which destined for export.

The methanol scandal is now completely absorbed.

Italian products today are equal if not superior to those of France which holds the record for pure propaganda. However, the methanol scandal had serious repercussions on the good name of Italian wine. This happened because some Piedmontese companies - in order to make up for a momentary shortage of product - put on the market a product with the addition of methyl, one of the most harmful alkalis for human health, which causes blindness and neurological damage.

Today, about 270 million hl of wine are produced worldwide. Of these, over 50 million $\mathrm{hl}$ are produced in Italy.

Today we talk about the old and new world of wine: European countries belong to the old world, to the new those still unknown markets such as China and India ${ }^{3}$. Due to climate change, many countries not dedicated to the production of wine are currently entering this sector, to the point that it is no longer easy to distinguish between the "old" world proper and the "new" one.

Currently, the country that consumes the most wine per capita is Portugal, consumption due to the fact that the country is an important tourist destination and therefore its consumption is increased by a massive presence of foreigners. In Italy, more or less the

\footnotetext{
${ }^{3}$ Indagine sul settore vitivinicolo, by Area Studi Mediobanca, April 2017
} 
same phenomenon occurs, and in addition it should be noted that in our country there are also regions that proceed in the opposite direction.

Campania, for example, boasts a wine consumption among residents higher than that consumed by tourists. In any case, Italy also produces "too much" wine, compared to the real demand. For all these reasons, it is necessary to think in terms of wine marketing and especially international marketing: selling wine abroad by combining it with foreign delicatessens is essential for increasing business and earning money in the wine sector.

Currently, Italy's market share is $13 \%$, of which $7 \%$ for wines costing more than $€ 7$; $17 \%$ for commercial wines whose price varies between 2 and 7 euros and 20\% for nonPremium wines, costing less than $2 €$. As for exports, Italy is second behind Spain for the quantity exported and second to France for the value of exports. The market share is $19 \%$ of which $15 \%$ for the Super premium; $24 \%$ for commercials and $20 \%$ for the remainder.

The analysis of these data quickly leads us to a series of reflections on the Italian wine sector, the sector is growing, positioning itself in third place after dairy and confectionery, and affects the national GDP by $13 \%$. These are important values that could also be considerably improved considering that our country boasts the largest number of vines in the world and also of varieties; 73 DOC wines against 5 from France and 3 from Spain.

The Italian wine system is a system strongly regulated by law. Until a few years ago, precisely in 2009, the wine CMO (Common Organization of Markets) was regulated separately from the agricultural CMO. In that year, the EC issued regulation 1234 which provides for their incorporation, incorporation valid until 2013, when the procedure, still in progress, began to further centralize the regulation, qualification and discipline measures.

There are four areas of application and among them the introduction of a file, the improvement of agricultural practices, the rules of sale and, of course, the protection of public health with the blocking of false or harmful adulterated products. Significant interventions were also made to protect the interests of wine producers. Regulation $1308 / 2013$ sets strict rules even with regard to oenological practices and products that can be used in the Union, providing - if nothing else - a single level of environmental protection and the quality of the final product.

Finally, Europe intervened also on the protection of wine quality, replacing the old legislation that classified wines among table wine, PGI and VQPRD (quality wines produced in a specific region). This classification was valid until 2009, today the legislation has reduced the entry limits in the various categories and the product can be defined, depending on the case, IGT, DOC, DOCG, and the possibility for producers of indicate also for wines with no territorial constraints or type of vine, the grape vinified and the vintage. 


\section{Chapter 3 Campania Wines}

The profile of Vesuvius on the Gulf of Naples, Positano and Amalfi on the rocks, dozens of archaeological sites scattered throughout the region, the scent of lemons. A fascinating background for an equally fascinating region, in which ancient customs and forgotten traditions are intertwined with wonderful naturalistic expressions.

This is Campania, a real "land of wine", capable of proposing - by itself - a number of vines equal to about one hundred, almost a quarter of the three hundred and fifty-five indigenous presents in Italy.

Colonized by the Greeks since the $8^{\text {th }}$ Century BC, Campania was called "Felix" by the ancient Romans and was known for some important wines like the Falernum, the favorite wine of the patricians and the Cecubo, still produced in the caldera of the extinct volcano of Roccamonfina.

Greek culture, in fact, had basically prepared the foundations for some excellences that would later assert themselves in Roman times and introduced in Campania some important grapes as the Aglianico.

After the profound agricultural crisis in medieval times, in Campania we start talking about wine again around the sixteenth century, when Sante Lancerio, who was the bottler of Pope Paul III, magnified the Greco di Somma, that of Ischia and that of Posillipo. Even the philosopher Giordano Bruno, in his Candelaio, mentions three wines from his land: the Malvasia di Candia, the Asprinio di Nola and of a sweet wine from Crete.

Although if devastated by the arrival of phylloxera from the Americas, in the nineteenth century, Campania was among the few Italian regions that managed to preserve the historic vines from the infamous insect, such as Tintore, still existing in the Sorrento Peninsula and capable of offering wines from vines over two hundred years old.

Although if devastated by the arrival of phylloxera from the Americas in the nineteenth century, Campania was among the few Italian regions that managed to preserve the historic vines from the infamous insect, such as Tintore, still existing in the Sorrento Peninsula and capable of offering wines from vines over two hundred years old.

However, the emigration due to the impoverishment of Campania following the unification of Italy caused, however, a depopulation of many areas and the fall into oblivion of many vines, which returned to the tables around the end of the 70s and the early 1980s.

Today there are many producers who invest in the wine sector in Campania, and in addition to the great names of viticulture in this region, such as Mastroberardino, there are many excellent producers throughout the territory, who offer very interesting wines, especially from gregarious grapes, i.e. grapes in the past rarely used in purity and which today are true specialities. 
The Campania vineyard area is currently 45,000 ha, a decrease of $30 \%$ compared to 2000. Production is dominated by the province of Benevento with $45 \%$ of the hectares, followed by that of Avellino with 30\%, Caserta with 15\% and close Naples and Salerno with the remaining $10 \%$. Most of the vineyards are located in the mountains, with a tentative increase in the average altitude ${ }^{4}$.

With four DOCG, 15 DOC and 16 PGI wines, Campania is a region whose $75 \%$ is made up of wines without appellation and medium-sized vineyards between one hectare and one and a half hectares, extremely small dimensions for a market with huge barriers to entry and exit as well.

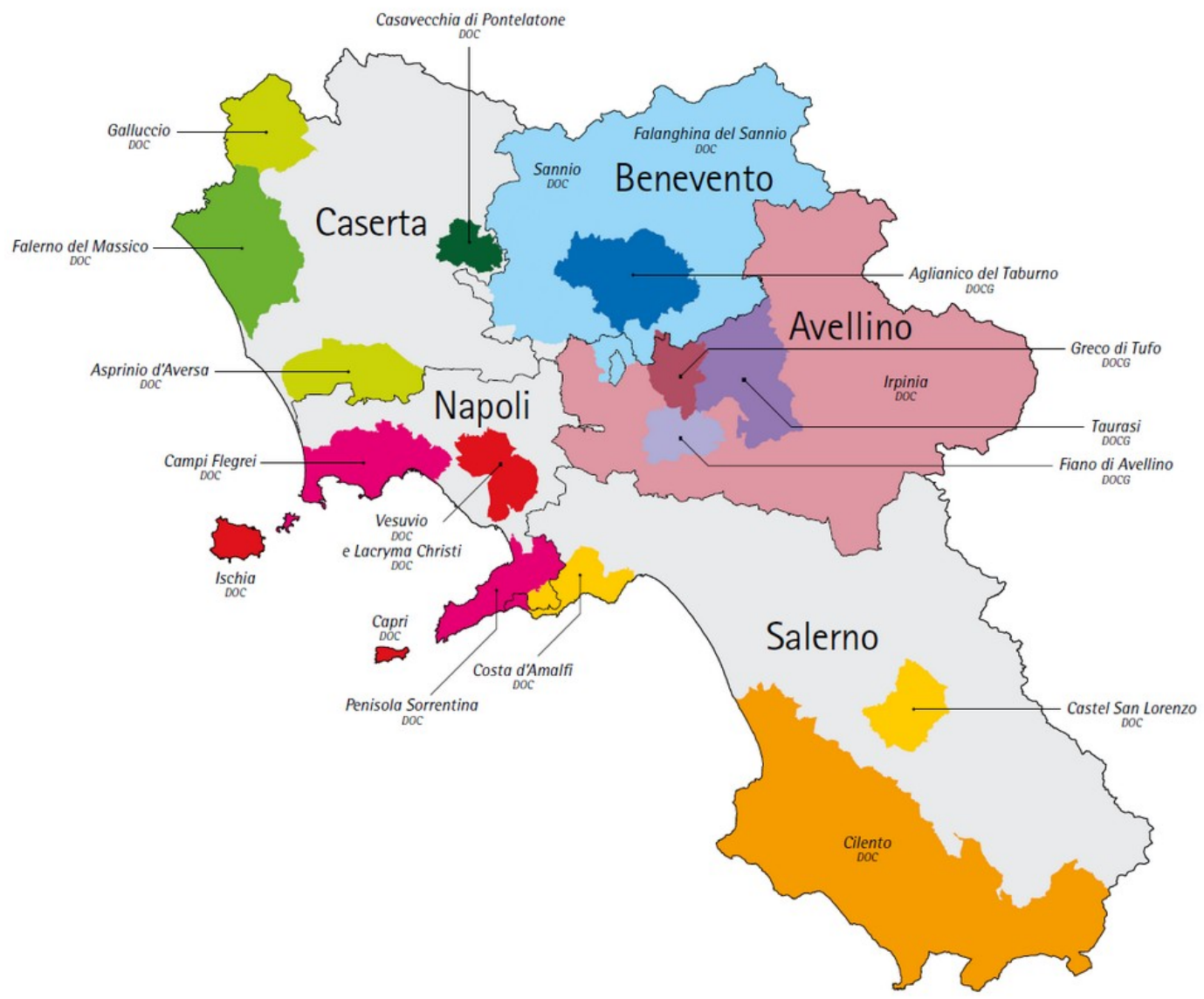

Fig. 2 - Wines of Campania Region

\footnotetext{
${ }^{4}$ OIV, World Viticulture Situation, 2015
} 


\section{Chapter 4 Economic Analysis of Campania Wine Market}

Companies in the wine sector - just like those in other sectors - are inclined to invest, whoever directs a company has every interest in ensuring that investments make the most of.

An industrially profitable investment may not be financially in same way, therefore it is necessary to understand the investment logic taking into account aspects that influence investments, economic resources and also common sense. ${ }^{5}$

Any company manager has the obligation to behave like the good father of a family who invests the resources at his disposal so that they give the maximum result.

The economic models designed for joint ventures are not applicable to wine companies, because a company that produces wine must take into account the nature and maturation processes of the final product. Some types of wine, in fact, require years of evolution before they can be sold and consequently it cannot depend on the revenues obtained from sales but must be able to self-finance and perpetuate itself over time, which means that the production must have a value always higher than the invested capital

Several models have been developed on the subject and the most interesting of all appears the so-called QUEENS, developed by prof. Rossi who hypothesizes 5 fundamental elements that the Italian system should use: Quality, Esternality, Innovation, Export, Network, Strategic process.

Italian wineyards and, in particular, those from Campania, suffer from a general difficulty in competing with the large world groups in the beverage sector. Finding a way to compete in such a difficult sector is, therefore, one of the most interesting problems in management studies.

Being able to locate a competitive arena on the demand side means knowing each consumer what alternatives he has available when making a particular purchase. This is the only way that Italian companies have to compete in such an abused sector, since - as we have seen - our companies remain family-run and do not have a solid management or marketing structure behind them capable of guiding their choices. and improve its competitiveness.

The merit of the SCP model, developed in the 1930s at Harvard, in the United States, generated "an evolution of studies in business strategy, especially as regards the emphasis on business results and the comparison between industry effects and firm effects ".

\footnotetext{
${ }^{5}$ ROSSI, M. (2008), Strategie Competitive del Settore Vitivinicolo, Aracne Editore, p.114
} 
Now, some scholars such as Porter, in the seventies and eighties, took inspiration from these studies and inverted the analysis framework of the structure-conduct-performance model in order to re-propose and apply it to the company. The objective of the strategy lies in the development of theories and models that can assist not so much those who make policies at the government level, but rather the managers of companies in finding the behaviors to adopt.

The model, known as the "Extended Competition Model", represents an essential reference framework for diagnosing competition. According to Porter, the rate of return on invested capital (ROI), within a sector, is determined by five competitive forces that affect companies: "in the struggle for market share, competition does not simply manifest itself in the form of other operators ${ }^{6}$.

The five competitive forces include three forms of horizontal competition - competition from suppliers of substitute products, the competitive threat of new antagonists and competition from established manufacturers - and two forms of vertical competition - the bargaining power of suppliers and buyers,

Now, in modern economies, the main consequence of technological innovation and production specialization is that of the offer of substitute products, that is, those that can satisfy the same need. The price of an asset, therefore, depends on whether or not there are products capable of replacing it and determines, moreover, the potential for profitability at the sector level. As a consequence of this, if substitute products are limited or non-existent, consumers will be inclined to pay a high price which generates inelastic demand relative to the price. The factors that determine the influence of substitute products are mainly two: propensity of buyers towards substitute products and price level.

\footnotetext{
${ }^{6}$ PORTER, M., How competitive forces shape strategy, Harvard Business School, 1979
} 


\section{Chapter 5 Conclusions}

Porter's model is undoubtedly valid for understanding the obstacles faced by a generic company and a generic entrepreneur who wants to invest in the wine sector.

This market, however, has unique characteristics, especially due to the existence of established producers for hundreds of years, who are now present on the market with established and high-end wines. For top-of-the-range wine we mean a wine whose value is only minimally influenced by mere cost. Basically, these are oenological products that meet specific needs and whose price is determined by the market.

It's time, now, to bring to an end the present work and it's useful, then, to understand how the Italian wineries, in particular those from Campania, grow and develop themselves in this sector.

We will begin by identifying the two main business models in the sector: that of agricultural production companies, which account for about $70 \%$ of the entire sector, and that of industrial and commercial production in the strict sense. The difference between the first two types essentially lies in the quality of the raw material.

The agricultural companies process at least $50 \%$ of their grapes, the industrialists buy more than that produced, the commercial ones do not produce grapes and buy everything they offer for sale.

There are two ways of distributing the products: the long chain, which from the producer. through the wholesaler, it passes to the consumer and the short chain, where the producer also acts as an entrepreneur/wholesaler. This second method, instead, provides, for obvious reasons, lower costs as the intermediate figure of the wholesaler is lacking.

This difference means that, over time, other distribution methods spreaded, including the distribution structures owned by the producers, the Italian distribution structures branched abroad, direct sales in GDO (Large Organized Distribution), chains of catering and the commercial Web. In the United States, by virtue of a law dating back to prohibition, this type of structure is not present and a manufacturer cannot also be a distributor.

Another development model, very different from the one illustrated, is the so-called external one, which consists in the acquisition of pre-existing companies. The disadvantages of this system are essentially three: difficulty of interaction / integration between companies; coexistence of processes in the various structures (Everything is produced simultaneously), inefficient production processes; on the other hand, an already thriving company is purchased, with a consolidated brand and productive knowhow. 


\section{References}

CASTALDO, F., Storia di vini e vigne attorno al Vesuvio. Il vino nella Campania antica dall’epoca Pompeiana alla fine dell’Impero Romano, Intra Moenia, 2016

CORSI, A. - MAZZARINO, S. - POMARICI, E., "Structural features of the Italian wine industry in The wine industry worldwide: toward a unique model of organization” Editors: Adeline ALONSO UGAGLIA, Luis Miguel ALBISU, JeanMarie CARDEBAT, Alessandro CORSI, Chema GIL, Simonetta MAZZARINO; 2017

FABBRINI, G. e MONTRONE, A., Economia Aziendale: Istituzioni, Franco Angeli, 2014

FORNI G., Quando e come sorse la viticoltura in Italia, in GACCI A., RENDINI P., ZIFFERERO A. (A cura di), Archeologia della vite e del vino in Etruria, CI.VIN., 2007

GALlETtO, L. e MALORGIO, G., Il Marketing del Vino, Capire, Decidere, Agire, Edises, 2017

LAMBIN, J., Market-driven management, Marketing strategico e operativo, McGrawHill, 2008

JOHNSON, H., Il Vino: storia, tradizioni, cultura, Franco Muzzio Editore, 2003

MOIO, L., Il respiro del vino, Mondadori, 2006

POMARICI, E., La struttura economica del comparto vitivinicolo italiano. Flussi, attori, competitività e collocazione internazionale, Cirve, 2016

PORTER, M., How competitive forces shape strategy, Harvard Business School, 1979

PORTER, M., Il vantaggio Competitivo, Einaudi, 2011

ROSSI, M., Strategie Competitive del Settore Vitivinicolo, Aracne Editore, 2008

SCARSO S., Marketing del Vino alle etichette ai social network, la guida completa per promuovere il vino e il turismo enogastronomico, Edizioni LSWR, 2017

SILVESTRONI, O. - PONI, S., Manuale di Viticoltura, Ed. Agricole, 2018 